\title{
IMPLEMENTASI PROGRAM PENGANGKUTAN SAMPAH DI KOTA BATAM TAHUN 2017
}

\author{
Muhammad Solihin 1 , Ronald Parlindungan ${ }^{2}$ \\ 'Program Studi Ilmu Pememrintahan Fakultas Ilmu Sosial dan Ilmu Politik Universitas Riau Kepulauan, \\ Indonesia \\ sm10rome@gmail.com \\ 2Program Studi Ilmu Pememrintahan Fakultas Ilmu Sosial dan Ilmu Politik Universitas Riau Kepulauan, \\ Indonesia \\ ronaldhsb@gmail.com
}

\begin{abstract}
Abstrak
Permasalahan pengangkutan sampah di Kota Batam menjadi masalah utama pemerintah karena gap tonase sampah dan armada pengangkut yang tidak berimbang sehingga menyebabkan tidak terangkutnya sampah di TPS hingga menimbulkan bau dan sumber penyakit. Manfaat penelitian ini dapat menjadi masukan pemerintah khususnya Dinas Lingkungan Hidup Kota Batam, Bagi masyarakat penelitian ini memberikan pengetahuan masyarakat tentang implementasi pengangkutan sampah di Kota Batam. Metode penelitian mengunakan pedekatan kualitatif dengan analisa deskriptif. Penelitian ini dilaksanakan pada bulan Mei-Oktober 2018. Tempat penelitian di Dinas Lingkungan Hidup Kota Batam. Tempat lain di lokasi Mitra pengangkutan sampah. Sumber data dipilih dengan teknik purposive sampling. Teknik pengeumpulan data dengan mengunakan wawancara, observasi dan dokumentasi. Teknik analisa data mengunakan reduksi data, penyajian data, dan penarikan kesimpulan. Hasil dan Pembahasan pada indicator input terdiri dari (1) Peraturan Daerah yang menjadi panduan Hukum, (2) Organisasi Pelaksana terdiri dari DLH Kota Batam, Kecamatan, dan Mitra, dan (3) Sumberdaya terdapat sumberdaya manusia, armada pengangkutan dan keuangan. Indicator output, (1) Akses, (2) Frekuensi (3) Cakupan, (4) Bias, dan (5) Ketepatan layanan secara umum dilakukan dengan baik walaupun terdapat beberapa hal yang perlu menjadi perhatian. Faktor yang mempengaruhi keberhasilan umumnya berjalan baik namun ada permasalahan krusial yakni kondisi lingkungan dan sumberdaya yang perlu ditingkatkan terus menerus sesuai dengan kondisi tonase.Kesimpulan pengangkutan sampah di Kota Batam pada Tahun 2017 sekitara 82 persen sampah telah ditanggulangi oleh Pemerintah dengan baikkecuali Kecamatan Belakang Padang, Galang Baru dan Bulang. Ada beberapa masalah teknis pengangkutan yang mesti diperhatikan seperti jumlah dan perawatan armada, jumlah satuan tugas, bin container yang tidak memakai tutup dan lain-lain. Faktor yang mempengaruhi keberhasilan, perlu ditingkatkan kesadaran masyarakat melalui sosialiasi dan lebih meminimalkan rumah liar, sumberdaya perlu ditingkatkan sesuai dengan kondisi tonase.

Kata Kunci: Implementasi Kebijakan, Pengangkutan Sampah, Tata Kelola Sampah.
\end{abstract}

\begin{abstract}
Abstrack
The problem of transporting garbage in Batam City is the main problem of the government because of the gap in waste tonnage and the unequal transport fleet which causes unloading of waste in the TPS to cause odor and source of disease. The benefits of this research can be the government's input, especially the Environmental Service of Batam City. For the community, this study provides public knowledge about the implementation of waste transportation in Batam City. The research method uses qualitative approach with descriptive analysis. This research was conducted in May-October 2018. The research site was in the Batam City Environmental Service. Other places in the location Trash transport partners. Data sources were selected by purposive sampling technique. Data collection techniques using interviews, observation and documentation. Data analysis techniques use data reduction, data presentation, and conclusion drawing. The results and discussion on input indicators consist of (1) Regional Regulations that become Legal guidelines, (2) Implementing Organizations consist of Batam City, District, and Partners, and (3) Resources are human resources, transport and financial fleets. Output Indicator, (1) Access, (2) Frequency (3) Coverage, (4) Bias, and (5) Service accuracy in general is well done although there are some things that need attention. Factors that influence success generally work well but there are crucial problems namely
\end{abstract}


environmental conditions and resources that need to be continuously improved in accordance with tonnage conditions. Conclusion The transport of garbage in Batam City in 2017 around 82 percent of the waste has been handled properly by the Government except the District of Belakang Padang, Galang Baru and Bulang. There are several technical transport problems that must be considered such as the number and maintenance of the fleet, the number of task forces, the container bin that does not use a lid and others. Factors influencing success, public awareness needs to be increased through socialization and minimizing wild houses, resources need to be improved according to tonnage conditions.

Keywords:Policy Implementation, Transport Garbage, Waste Management.

\section{PENDAHULUAN}

Provinsi Kepulauan Riau merupakan wilayah kepulauan dengan terdiri dari lebih 300 pulau. Salah satu pusat ekonomi di Provinsi ini adalah kota Batam yang terdiri dari Batam, Rempang dan Galang. Saat ini jumlah penduduk kota Batam per 2015 berjumlah 1.020.529 jiwa. Diperkirakan penduduk akan tumbuh sekitar 2,8 Juta jiwa pada tahun 2037.

Dengan estimasi peningkatan penduduk tersebut Kota Batam tentu tidak luput dari masalah-masalah sosial seperti kota-kota besar lainnya di Indonesia. Salah satu masalah yang dihadapi adalah permasalahn sampah. Seiring dengan meningkatnya jumlah populasi di Kota Batam tentu juga akan diiringi peningkatkan jumlah sampah dari konsumsi rumah tangga, industri dan lain-lain. Sampah Kota Batam saat ini dikelola oleh Dinas Kebersihan dan Pertamanan (DKP) dan Mitra oleh PT Royal Gensah Asih (RGA) sampai tahun 2016. Sampah tersebut dibawah ke Tempat Pembuangan Akhir (TPA) Telaga Punggur yang dioperasikan oleh DKP.

TPA Telaga Punggur di rancang oleh BP Batam pada tahun 1997 sebagai landfill saniter dengan luas sebesar 2,5 hektar wilayah permukaan TPA. Selanjutnya pada tahun 2002 operasi diserahkan kepada Kota Batam. Namun diperkirakan TPA Telaga Punggur saat ini akan berusia kurang dari 10 tahun dikarenakan kapasistas. Di kota Batam saat ini terdapat kurang lebih 600 ton sampah per hari yang dibuang ke TPA pada 2012. Sedangkan data sampah per tahun di Kota Batam pada tahun 2006 sekitar 165.279 ton/tahun, meningkat pada tahun 2012 menjadi 251.918 ton/pertahun. Jika diprosentase 6 tahun terakhir sampah di Kota Batam naik 52,4 persen.

Hasil forecasting jumlah sampah pada tahun 2017, 2025, 2035, dan 2045 maka akan terlibat seperti Gambar 1 sebagai berikut: 


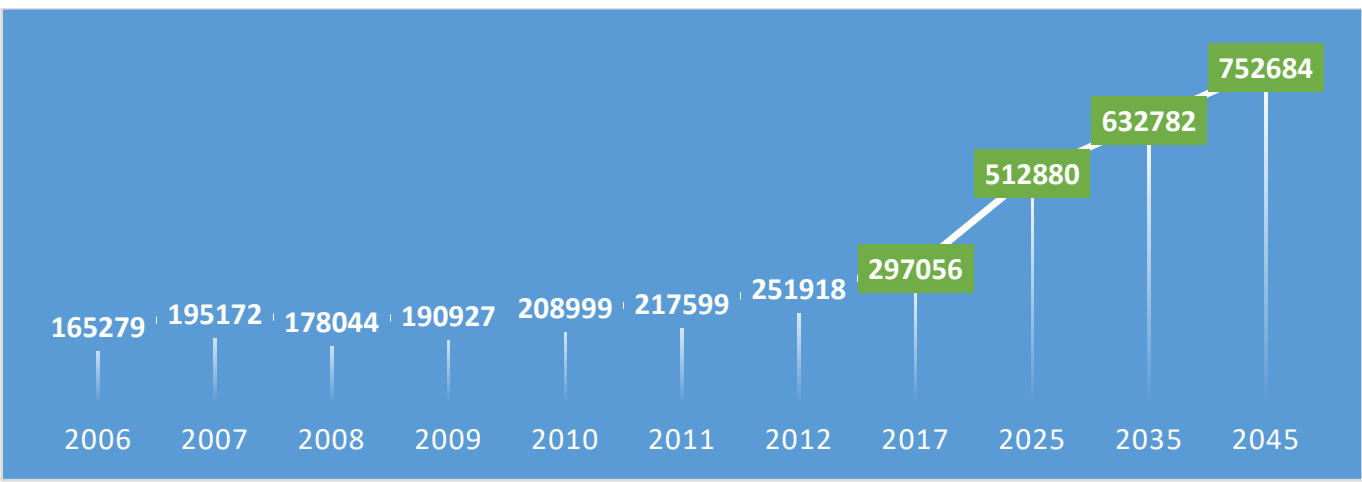

Gambar 1. Proyeksi Jumlah Sampah di Kota Batam Berdasarkan Ton/Tahun 2006-2045 Sumber: Diolah Peneliti 2017

Berdasarkan proyeksi tersebutjumlah sampah di Kota Batam pada tahun 2017 (297.056 ton/tahun), meningkat pada 2025 (512.880 ton/tahun), 2035 (632.783 ton/tahun) dan 2045 (752.684 ton/tahun). Jika melihat jumlah sampah pertahun Kota Batam yang diproyeksi semakin banyak tentu masalah pengangkutan sampah di Kota Batam juga akan menjadi semakin rumit. Pada tahun 2014 - 2015sempat ada masalah penangangan sampah dikarenakan tonase sampah dengan jumlah armada tidak sebanding. Studi kasus pada tahun 2014 PT RGA mengalami masalah tersebut dikarenakan sampah sudah melebih 450 ton/hari. Akhirnya sampah menumpuk dan menimbulkan bau. Masyarakat Kota Batam juga banyak melayangkan protes ke pemerintah pada saat itu.

Pada tahun 2016 mulailah ada peralahihan pengangkutan sampah yang dulu bermitra dengan pihak ketiga, sekarang dialihkan ke Pemerintah Kota Batam melalui Dinas Lingkungan Hidup (DLK). Pada tahun 2017 terhitung 1 januari Pemerintah Kota Batam melalui Dinas Lingkungan Hidup Bidang Pengelolaan Persampahan, mendelegasikan urusan pengangkutan sampah di kecamatan. 


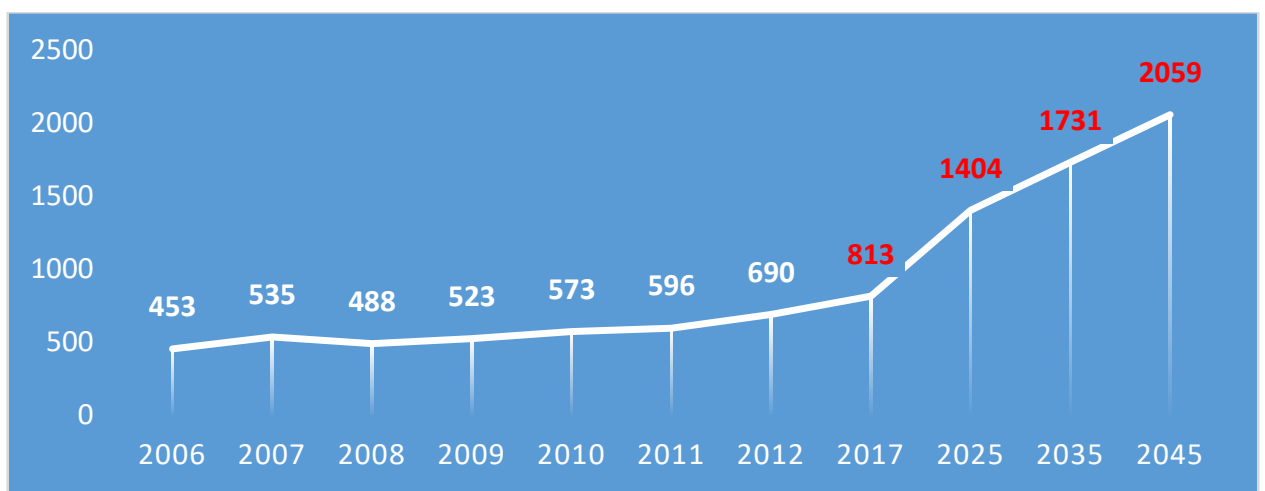

Gambar 2. Proyeksi Jumlah Sampah di Kota Batam Berdasarkan Ton/Hari 2006-2045 Sumber: Diolah Peneliti 2017

Problem pengangkutan sampah di Kota Batam akan bertambah pelik jika tidak direncanakan dengan matang pengelolaanya. Jika di proyeksi jumlah sampah ton/hari tahun 2017 (813 ton/hari), 2025 (1404 ton/hari), 2035 (1.731 ton/hari), dan 2045 (2.056 ton/hari) seperti pada Gambar 1.4 dibawah ini tentu permasalahan pengangkutan sampah akan masalah utama pemerintah karena gap tonase sampah dan armada pengangkut. Dalam penelitian ini peneliti akan melihat implementasi program pengangkutan sampah di Kota Batam tahun 2017 yang dilaksanakan oleh Dinas Lingkungan Hidup Bidang Pengelolaan Sampah Kota Batam.

\section{METODELOGI}

Tempat penelitian di sekretariat Dinas Lingkungan Hidup Kota Batam. Tempat lain di lokasi Mitra pengangkutan sampah. Jenis penelitian ini mengunakan pendekatan kualitatif dengan analisa deskriptif. Metode deskriftif diartikan sebagai prosedur pemecahan, masalah yang diselidiki dengan mengambarkan objek yang diteliti, seperti idividu, lembaga, masyarakat dan lain-lain, pada saat sekarang berdasarkan fakta-fakta yang tampak atau sebagaimana adanya (Nawawi, 1992: 63). Bogdan \& Taylor dalam Moleong (2007: 4) mendefinisikan metode kualitatif sebagai prosedur penelitian yang menghasilkan data deskriptif berupa katakata tertulis atau lisan dari orang-orang dan perilaku yang dapat diamati. Jenis Data yang dikumpulkan untuk penelitian ini berupa data primer dan data sekunder.

Pengumpulan data dalam penelitian ini mengunakan teknik purposive sampling. Teknik ini digunakan untuk memperoleh informan dalam organisasi atau kelompok yang terbatas untuk menemukan informan yang tepat. Adapun sumber data peneliti adalah: 
Tabel 1. Responden Penelitian

\begin{tabular}{|l|l|l|}
\hline No & Nama & Jabatan \\
\hline 1 & Faisal Novrico, MPA & Kepala Bidang Pengolahan Sampah \\
\hline 2 & Muldiarman, S.T & Kepala Seksi Penanganan Sampah \\
\hline 3 & Rida Meliyana, S.E & Kepala Seksi Pengurangan Sampah \\
\hline 4 & Delfery, S.T & Sekretaris Camat Sekupang \\
\hline 5 & Maryanto, S.E & Kepala Seksi Ketentraman dan Ketertiban \\
\hline 6 & Sela & Masyarakat Patam Lestari, Sekupang \\
\hline 7 & Rizqi & Masyarakat Sungai Harapan, Sekupang \\
\hline 8 & Yoga & Masyarakat Batam Centre \\
\hline 9 & Rafi & Masyarakat Sagulung \\
\hline
\end{tabular}

Sumber: Diolah Oleh Peneliti 2018

Teknik Pengumpulan Data (Sugiyono, 2009): Observasi adalah belajar tentang perilaku dan makna dari perilaku tersebut.Wawancara, adalah merupakan pertemuan dua orang untuk bertukar informasi dan ide melalui tanya jawab, sehingga dapat dikonstruksikan makna dalam suatu topik tertentu. Dokumentasi adalah catatan peristiwa yang sudah berlalu. Dokumen bisa berbentuk tulisan, gambar, atau karya-karya monumental dari seseorang. Analisis data dalam penelitian ini menggunakan Model Interaktif menurut Miles dan Hubberman dalam Sugiyono (2011: 224). Analisis model interaktif tersebut, terdiri dari pengumpulan data, reduksi data, penyajian data, dan penarikan kesimpulan.

\section{PEMBAHASAN}

Menurut Purwanto dan Sulistyastuti (2012: 21) implementasi adalah kegiatan untuk mendistribusikan keluaran kebijakan (to delivery policy output) yang dilakukan oleh para implementer kepada kelompok sasaran (target group) sebagai upaya untuk menwujudkan tujuan kebijakan. Dalam penelitian melihat implementasi program pengangkutan sampah di Kota Batam meminjam istilah William Dunn (2003) menyebutnya implementasi kebijakan (Policy Implementation) adalah pelaksanaan pengendalian aksi-aksi kebijakan di dalam kurun waktu tertentu. Penulis akan melakukan pembahasan dari dua indikator implementasi kebijakan.Implementasi program di lapangan yang dimana akan dinilai dari (1) Indikator masukan kebijakan (policy input); (2) Indikator Output. Berikut analisis penulis mengenai 2 indikator tersebut dalam penelitian ini.

\section{MASUKAN KEBIJAKAN}

Input kebijakan adalah (sumberdaya) yang dipakai untuk menghasilkan produk dan layanan dari suatu program dan layanan dari suatu program. Adapun sumberdaya yang 
dipakai dalam penelitian ini adalah (1) Peraturan Daerah; (2) Organisasi Pelaksana; dan (3) Sumberdaya.

\section{Peraturan Daerah}

Peraturan Daerah yang mengatur adalah Peraturan Kota Batam No 11 Tahun 2013 Tentang Pengelolaan Sampah pada pasal 22 adalah sebebagai berikut:

1. Pengangkutan sampah dilaksanakan dengen sistem langsung dan tidak langsung;

2. Pengangkutan sampah selain dilakukan oleh Dinas, dapat dilakukan oleh pengelola kawasan permukiman dan pihak ketiga (mitra);

3. Pengangkutan sampah dilakukan dengan membawa sampah dari sumber sampah ke TPS/TPST/TPA, atau dari TPS/TPST ke TPA;

4. Pemerintah Daerah menyediahkan Stasiun Peralihan Antara untuk mendukung kegiatan pengangkutan sampah;

5. Pengangkutan sampah dilaksanakan dengan cara yang menjamin tetap terpilahnya sampah berdasarkan jenis sampah, hingga ke TPS/TPST/TPA, dan tidak tercecer di perjalanan selama dalam proses pengangkutannya; dan

6. Sampah diangkut dengan menggunakan alat pengangkut sampah yang memenuhi standar sesuai dengan ketenteuan peraturan berlaku.

\section{Organisasi Pelaksana}

Adapun organisasi pelaksana dalam pengangkutan sampah di Kotam Batam yakni : (1) Dinas Lingkungan Hidup Kota Batam, (2) Kecamatan, dan (3) Mitra/Transporter.

Adapun sumberdaya manusia yang ada di Dinas Lingkungan Hidup Kota Batam adalah 904 Satuan Tugas terdiri dari Supir, Kernet, Mekanik, dan lain-lain. Sedangkan Fasilitas dalam pengangkutan sampah di Dinas Lingkungan Hidup Kota Batam adalah Dump Truck 52 buah, Arm Roll Truck 54 buah, Convektor 10 buah, Pick Up 2 buah, Becak Motor 2 buah, Buldoser 2 buah, dan Eskavator 2 buah. Adapun fasilitas yang dihibahkan ke Kecamatan dalam hal untuk pelaksanaan pengangutan sampah di Kota Batam adalah sebagai berikut per Juni 2017 berjumlah 51 Pick Up. Gaji dari satuan tugasdi Dinas Lingkungan Hidup Kota Batam adalah sebesar Rp 3.511.500/Bulan di potong uang BPJS Ketenagakerjaan. 


\title{
LUARAN KEBIJAKAN
}

Indicator policy output adalah keluaran (output) kebijakan berupa produk dan layanan publik yang dapat dinikmati oleh kelompok sasaran. Dalam penelitian ini peneliti akan menceritakan produk dan layanan publik berupa pengangkutan sampah di Kota Batam yang dijalankan pada tahun 2017. Dalam policy output ini peneliti mengunakan indicator policy output yang dingunakan oleh yang ditawarkan oleh Ripley (Purwanto dan Sulistyastuti, 2012) yakni (1) Akses; (2) Frekuensi; (3) Cakupan; (4) Bias; dan (5) Ketepatan Layanan.

\begin{abstract}
Akses
Akses dalam pengangkutan sampah di Kota Batam terdiri dari cara berikut (1) Pengangkutan dari sumber sampah ke Tempat Pembuangan Sementara (TPS), pengangkutan biasanya mengunakan pick up dan becak motor; (2) Pengangkutan sampah dari TPS menuju ke Tempat Pembuagan Akhir (TPA); dan (3) Pengangkutan Sampah dari Sumber Sampah Ke TPA.
\end{abstract}

\section{Frekuensi}

Untuk frekuensi pengangkutan sampah di Kota Batam berdasarkan keterangan dari Kepala Bidang Pengelolaan sampah, Faisal Noverico, MPA bahwa :

1) Pengangkutan dari sumber sampah ke tempat pembuangan sementara (TPS) dilakukan oleh kecamatan dengan jadwal 2 kali pengakutan dalam 1 minggu; dan

2) Pengangkutan sampah dari TPS menuju ke tempat pembuagan akhir (TPA) dilakukan oleh oleh DLH Kota Batam setiap hari.

Hal ini juga diperkuat oleh pernyataan Sekretaris Camat Sekupang Bapak Delfery ST:

"di Kecamatan Sekupang pick up kami beserta armada mengambil sampah di rumah rumah seminggu rata-rata 2 kali angkut. Dan tidak hanya di rumah-rumah namun juga dijalan-jalan" (12/9/2018)

Namun pengangkutan sampah dari rumah juga dilakukan lebih dari 2 kali dalam seminggu jika sampah menumpuk yang dijelaskan oleh kutipan wawancara dengan Kasi Ketentraman dan Ketertiban, Maryanto, S.E.

"pengangkutan sampah di Kecamatan Batu Aji dilakukan 2 kali dalam 1 minggu, dari perumahan satu dan perumahan lainnya, namun terkadang bisa menadi 3-4 kali trip karena sampah yang lebih banyak" (12/9/2018) 
Sampah saat ini banyak terjadi kelebihan tonase, untuk itu armada yang seharusnya mengangkut 1-2 trip perhari, bisa saja sampai 4 trip perhari. Berikut gambar 2 mengambarkan keadaan kelebihan tonase yang terjadi di lapangan.

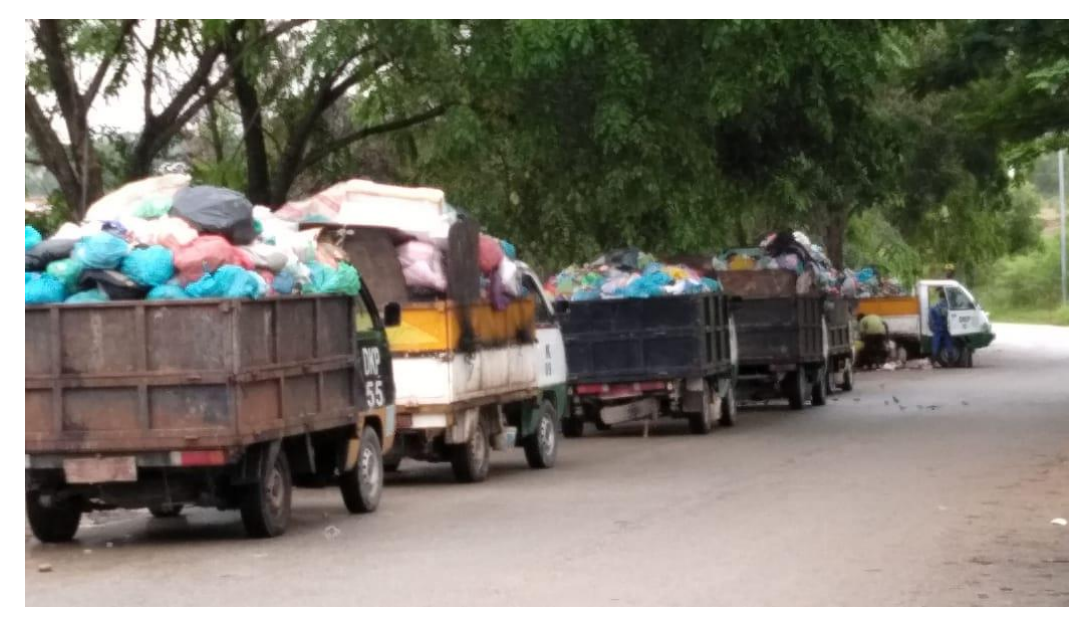

\section{Gambar 3. Kelebihan Tonase Di Kecamatan Sekupang Sumber: Dokumentasi Peneliti 2018}

\section{Cakupan}

Indikator ini digunakan untuk menilai berapa besar kelompok sasaran yang dapat dijangkau oleh kebijakan yang diimplementasikan. Pengangkutan sampah di Kota Batam yang dilaksanakan oleh Dinas Lingkungan Hidup Kota Batam yakni ada di 9 kecamatan.

Tabel 2. Tonase Sampah di Kecamatan Bulan Juni Tahun 2017

\begin{tabular}{|l|l|r|}
\hline No & Kecamatan & Juni (Ton/Hari) \\
\hline 1 & Sekupang & 82.850 Ton/Hari \\
\hline 2 & Batu Aji & 88.830 Ton/Hari \\
\hline 3 & Sagulung & 86.210 Ton/Hari \\
\hline 4 & Sei Beduk & 29.890 Ton/Hari \\
\hline 5 & Batam Kota & 129.270 Ton/Hari \\
\hline 6 & Nongsa & 22.950 Ton/Hari \\
\hline 7 & $\begin{array}{l}\text { Lubuk Baja, Bengkong, dan Batu } \\
\text { Ampar }\end{array}$ & 26.120 Ton/Hari \\
\hline 8 & Taman dan Dump Truck & 279.000 Ton/Hari \\
\hline 9 & Dump Truck dan Pick Up & 33.690 Ton/Hari \\
\hline 10 & Convector Besar & 829.540 Ton/Hari \\
\hline Jumlah Sumber: DLH Kota Batam 2018 \\
\hline
\end{tabular}

Cakupan dalam pengangkutan sampah sendiri berdasarkan wawancara dengan Kepala Bidang Pengelolaan Sampah DLH Kota Batam, Bapak Faisal Novrico, MPA hanya dilakukan di 9 kecamatan saja. 
"untuk pengakutan sampah saat ini kita hanya melakukan pengangkutan sampah di kawasan mainland(Darat) yakni di Sembilan kecamatan. Kecamatan yang tidak yakni Kecamatan Belakang Padang, Bulang, dan Galang. Namun di tiga kecamatanan tersebut pengelolaan sampah di lakukan oleh kecamatan dengan bantuan RT/RW setempat" (10/09/2018)

Pada kutipan diatas bahwa terdapat 3 Kecamatan yang tidak dapat di jangkau oleh DLH Kota Batam dikarena keterbatasan anggaran dan fasilitas. Namun di tiga kecamatan tersebut masalah pengelolaan sampah telah dilimpahkan di masing-masing Kecamatan dengan swakelola dengan melibatkan RT/RW di wilayah masing-masing. DLH dalam pengangkutan sampah tidaklah bekerja sendiri, namun juga ada peran serta dari mitra/transpoter yang membantu dalam teknis pengangkutan sampah. Menurut data diatas dalam rentang tahun 2017 pengangkutan sampah yang dilakukan oleh pihak mitra sebanyak 51.435.010 ton/tahun (18,14 persen), sedangkan DLH Kota Batam mengangkut 232.041.600 ton/tahun (81.86 Persen). Jika dibandingan dengan Tahun 2016, pengangkutan sampah pada 2017 memang masih melibatkan pihak swasta namun dengan porsi yang lebih sedikit.

Tabel 3. Tonase Sampah Mitra, Industri, DLH Kota Batam Tahun 2016-2017

\begin{tabular}{|l|l|l|l|}
\hline No & & 2016 & 2017 \\
\hline 1 & Mitra & 107.284 .540 ton/Tahun & 51.435 .010 ton/Tahun \\
\hline 2 & Industri & 62.521 .723 ton/tahun & 0 \\
\hline 3 & Dinas & 128.412 .690 ton/Tahun & 232.041 .610 ton/Tahun \\
\hline \multicolumn{2}{|l|}{ Total } & 298.218.953 Ton/Tahun & 283.476.610 Ton/Tahun \\
\hline
\end{tabular}

Sumber: DLH 2018

Pada tabel diatas ini pada 2016 terlihat pihak mitra masih mendominasi pengangkutan sampah di Kota Batam. Angkutan sampah sebesar 36 persen (107.284.540 ton/Tahun) diangkut oleh pihak Mitra dan angkutan sampah Industri 21 persen (62.521.723 ton/Tahun). Jika ditotal pada Tahun 2016 pihak swasta lebih banyak berperan dalam pengangkutan sampah di Kota Batam yakni 57 persen (169.806.263 ton/Tahun), sedangkan Dinas Kebersihan dan Pertamanan pada saat itu hanya mengangkut 43 persen $(128.412 .690$ ton/Tahun) sampah di Kota Batam.

Berbeda dengan tahun 2016, Pada Tahun 2017 pengelolaan sampah di selenggarakan oleh Dinas Lingkungan Hidup Kota Batam. Pada tahun pertama ini DLH Kota Batam masih melibatkan pihak swasta namun dengan porsi yang minimal jika dibandingkan denganTahun 2016. Angkutan sampah pada tahun 2017 yang dilakukan oleh pihak mitra (swasta) sebanyak 51.435.010 ton/tahun (18,14 persen), sedangkan DLH Kota Batam mengangkut 232.041.600 ton/tahun (81.86 Persen). 


\section{Bias}

Dalam pengangkutan sampah DLH Kota Batam telah menjalan program utama mereka yakni mengangkut sampah di Kota Batam dari sumber sampah ke TPS, lalu dari TPS ke TPA Telaga punggur. Namun pada pelaksanaannya berdasarkan observasi penulis di lapangan terdapat pelanggaran kecil yang dilakukan oleh satgas yang dilakukan di lapangan dengan memilah sampah yang bernilai ekonomis ke tempat terpisah untuk mendapat uang tambahan.

Kepala Bidang Pengelolaan samapah Faisal Novrico,

"pada saat dilapangan memang ada teman-teman dilapangan memisahkan barang-barang yang bernilai ekonomi, namun tetap kami sampaikan bahwa tugas utama dari satgas pengangkutan sampah adalah mengangkut sampah. Untuk memilah barang yang memiliki nilai ekonomis jelas itu tidak boleh dan tidak ada dalam tupoksi kami”

Dalam kutipan diatas jelas bahwa tidak diperkenankan untuk mengangkut barang yang bernilai eknomis oleh petugas pengangkutan sampah dikarenakan itu bukan tugas mereka.

Pada Perda Kota Batam no 11 Tahun 2013 tertulis bahwa Pemerintah Daerah menyediahkan Stasiun Peralihan Antara untuk mendukung kegiatan pengangkutan sampah. Dalam menyediaan Stasiun Peralihan Antara atau Tempat Pembuangan Sampah yang berupa bin container telah dilakukan oleh Pemko Batam dengan di 7000 titik di Kota Batam berdasarkan keterangan dari Bapak Faisal Novrico, Kepala Bidang Pengelolaan Sampah, DLH Kota Batam.

"iya untuk tempat pembuangan sampah sampah sementara di Kota Batam kita memiliki 7000 titik di Kota Batam yang tersebar di perumpahan kawasan pertokohan dan lain-lain"

Namun berdasarkan observasi peneliti TPS-TPS tersebut di dominiasi oleh TPS yang mengunakan badan jalan sebagai tempat pembuagan sementara dan hampir mayoritas TPS tidak memiliki tutup. Seperti TPS berikut ini: 


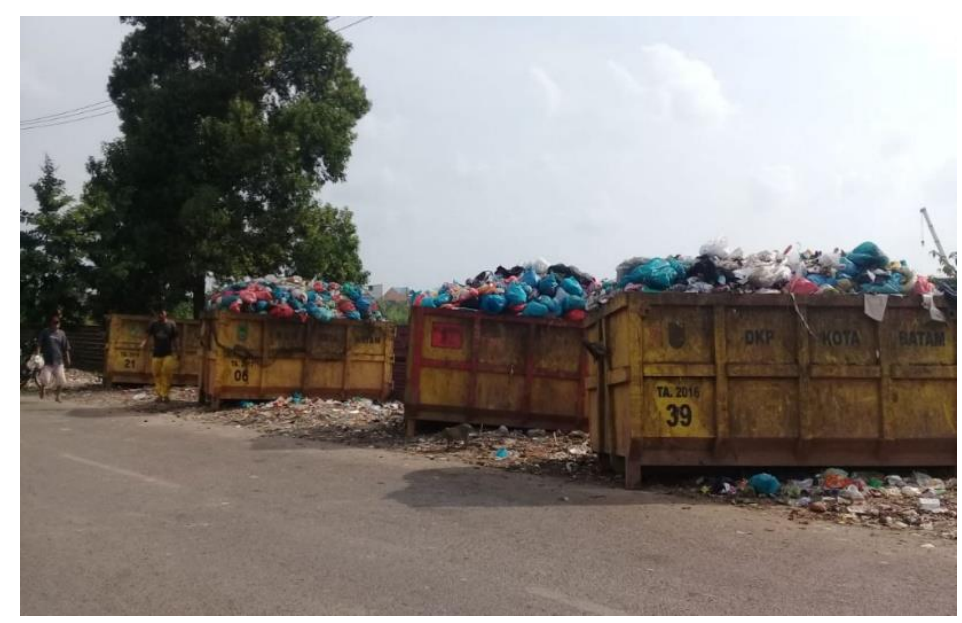

Gambar 4. TPS Mengunakan Badan Jalan di Sagulung Sumber: Dokumentasi Peneliti 2018

Pada Perda Kota Batam no 11 Tahun 2013 tertulis pada pasal 21 Pengangkutan sampah dilaksanakan dengan cara yang menjamin tetap terpilahnya sampah berdasarkan jenis sampah, hingga ke TPS/TPST/TPA, dan tidak tercecer di perjalanan selama dalam proses pengangkutannya. Untuk pengangkutan sampah biasanya Armada DLH Kota Batam mengunakan jaring dalam pengangkutannya sehingga meminimalkan potensi terjadinya sampah yang tercecer. Namun untuk terpilahnya jenis sampah saat ini dalam pangangkutan sampah belum dilakukan oleh pihak pemerintah secara maksimal dikarenakan tempat sampah di rumah-rumah atau sumber sampah hanya tersedia satu jenis tempat sampah. Berikut keterangan dari M Rafi (22) Masyarakat Sagulung:

"tempat pembuangan di depan rumah saya cuma satu bak sampa warnanya biru, disatu bak itulah biasanya kami membuang sampah plastik, sisa makanan , dan lain-lain" (1/10/2018)

Berdasarkan keterangan dari Ibu Rida Meliyanan S.E, Selaku Kepala Seksi Pengurangan Sampah DLH Kota Batam.

"untuk pengurangan sampah sendiri kita mengalakan proses pemilahan sampah berbasis masyarakat dengan cara memisahkan sampah dari sumbernya. Saat ini terdapat sebanyak 260 Bank Sampah yang tersebar di 10 Kecamatan di Kota Batam"

Dalam hal pemilahan sampah sendiri tidak begitu masif terjadi dikarenakan tempat sampah di rumah-rumah (sumber sampah) masih terdiri dari satu tempat sampah saja. Sehingga memang dari sumber sampah kebanyakan sampah memang belum terpilah. 


\section{Ketepatan Layanan}

Digunakan untuk menilai apakah layanan yang diberikan dalam implementasi program dilakukan tepat waktu atau tidak. Sudah jelas bahwa penggunaan indikator ini mengacu kepada program yang memiliki sensitifitas waktu atau dilakukan pada saat waktu yang tepat.

Pengangkutan sampah dari sumber sampah menurut On Schedule DLH Kota Batam 2017, pengangkutan sampah dari sumber sampah dilakukan oleh Kecamatan yakni 1 minggu 2 kali untuk masing-masing titik sampah perumahan.

Hal ini seperti yang dinyatakan oleh Sekretaris Camat Sekupang, Bapak Delferry S.T dan Kasi Ketentraman dan Ketertiban, Bapak Maryanto S.E yang menyatakan bahwa Pick Up kecamatan melakukan penyisiran sampah di perumahan sebanyak 2 kali dalam seminggu.

Pada perumahan Tanjung Sakina, Tiban Mentarau, Patam Lestrari, Sekupang Ibu Sella (38) salah satu penghuni Perumahan tersebut membenarkan bahwa pengangkutan sampah di rumahannya dilakukan 1 minggu 2 kali, namun perna terjadi pengangkutan sampah dilakukan 1 minggu satu kali.

"iya di perumahan Tanjung Sakina ini, sampah diangkut 1 minggu 2 kali, tepatnya 3 hari sekali, tapi perna juga cuma 1 kali dalam seminggu, kami si selama sampah tidak menumpuk ya ga masalah"

Pada perumahan Permata Hijau di Sagulung, M Rafi (22) menjelaskan bahwa diperumahannya sampah diangkut 1 minggu 1 kali.

"di perumahan Permata Hijau, sampah diangkut 1 kali dalam 1 minggu, namun sampah dibersihkan semua, tapi selama seminggu tersebut sampah sudah mulai bau" (1/10/2018)

\section{FAKTOR-FAKTOR YANG MEMPENGARUHI}

\section{Kondisi Lingkungan}

Lingkungan sangat mempengaruhi implementasi kebijakan, yang dimaksud lingkungan ini mencakup lingkungan sosio cultural serta keterlibatan penerima program. Pemukiman kumuh di Kota-kota besar selalu saja menjadi masalah yang tidak kunjung bisa di selesaikan. Begitupun halnya Di Kota Batam tidak sedikit jumlahnya pemukiman kumuh yang ada di Kota Batam. Tentu keberadaan rumah liar yang statusnya tidak diakui oleh pihak 
pemerintah membuat mereka tidak mendapat beberapa pelayanan dasar seperti listrik, air, gas kota, dan juga layanan angkutan sampah.

Menurut Bapak Muldi Arman S.T, Kepala Seksi Penanganan Sampah DLH Kota Batam untuk warga yang tinggal di Rumah Liar sampah tidak diangkut sampahnya, namun mereka secara mandiri mengantar sampah mereka ke bin container terdekat dari rumah mereka dengan tidak membayar sama sekali.

"ada beberapa ruli yang tidak kami layani pengangkutan sampahnya seperti di Seraya atas, Bengkong, Belian dan lainnya. Tapi tidak mungkin mereka menumpuk sampah di depan rumah mereka karena pasti bau, mereka biasanya membawa sampah ke tempat sampah"

Selain itu budaya masyarakat membuang sampah tidak pada tempatnya juga menjadi kendala dilapangan untuk DLH Kota Batam. Seperti membuang sampah ke DAS (Daerah Aliran Sungai) dan tidak membuang sampah tepat ke Bin Container.

\section{Hubungan Antar Organisasi}

Dalam banyak program, implementasi sebuah program perlu dukungan dan koordinasi dengan instansi lain. Untuk itu diperlukan koordinasi dan kerjasama antar instansi bagi keberhasilan suatu program. Dalam suatu program tentu akan melibatkan banyak intansi dalam pelaksanaannya. Dalam program pengakutan sampah di Kota Batam pada Tahun 2017 terdapat beberapa instasi yang sangat berperan di dalamnya seperti Dinas Lingkungan Hidup, Kecamatan, dan Transporter (mitra). Menurut Bapak Faisal Novrico, Kepala Bidang Pengelolaan Sampah DLH Kota Batam DLH dan Kecamatan memiliki waktu koordinasi 1 tahun 4 kali untuk membahas jadwal pengangkutan sampah di Kota Batam. Selain itu koordinasi juga dilakukan pada saat hari-hari besar yang biasanya diperkirakan meningkatnya sampah dari hari biasa.

“iya untuk koordinasi dengan camat itu pasti, karena sejak tahun 2016 urusan kebersihan juga telah dilimpahkan oleh Walikota menjadi tangungjawab mereka juga, kami lakukan koordinasi 3 bulan sekali untuk membahas schedule/jadwal. Selain itu pada hari-hari besar juga. Namun bukan berarti hari-hari biasa kami tidak koordinasi, kami selalu berkoordinasi karena disetiap kecamatan kami memiliki tim pengawas yang diduduki oleh kasi yang membidangi masalah kebersihan"

Setelah DLH Kota Batam berkordinasi dengan kecamatan, selanjutnya kecamatan juga secara top down juga berkoordinasi di tingkat lurah dan forum RT/RW yang saat ini 
dengan mudah mereka lakukan melalui group WA (whatsapp) seperti yang dilakukan oleh Kecamatan Sekupang berdasarkan kutipan wawancara dengan Bapak Delferry S.T Sekretaris Camat Kecamatan Sekupang.

"untuk kebersihan di kecamatan Sekupang kami ada yang namanya forum RT/RW yang pada saat tertentu seperti adanya penyumbatan di Daerah Aliran Sungai di Kelurahan Tiban Lama, atau hari-hari besar kami perintahkan untuk melakukan GORO bersama dengan dikoordinasi oleh Kelurahan"

Pihak kecamatan juga secara rutin mengkontrol satgas pengakutan sampah yang berada dibawahnya. Selain itu ada juga koordinasi DLH Kota Batam dengan pihak Mitra Pengangkut sampah atau Transporter. DLH Kota Batam mempunyai wewenang memerikan surat izin pengangkutan sampah sejenis sampah rumah tangga kepada Transpoter yang memenuhi syarat dan tentu mitra tersebut harus tunduk dengan aturan yang dibuat oleh DLH Kota Batam. Izin mitra tersebut berlaku selama 5 Tahun dan wajib melakukan pendaftaran kembali setiap tahunnya.

\section{Sumberdaya}

Implementasi kebijakan perlu didukung sumberdaya baik sumberdaya manusia (human resources) maupun sumberdaya non-manusia (non human resources). Pada Tahun 2017 sumberdaya manusia di DLH Kota Batam memiliki satgas yang berjumlah 904 orang dan jumlah Armada sebanyak 124 buah. Jumlah tersebut di Tahun 2018 tidak banyak berubah. Hal ini akan bermasalah jika gap tonase sampah dan armada tidak berbanding lurus peningkatannya. Hal ini akan menyebabkan penumpukkan sampah dan akhirnya sampah tidak terangkut. Sebaiknya dengan proyeksi yang dilakukan jumlah armada dan personil Satuan Tugas juga harus bertambah secara bertahap sesuai jumlah tonase sampah. Bapak Faisal Novrico, Kepala Bidang Pengelolaan Sampah DLH Kota Batam menjelaskan:

"tentu jumlah sumberdaya manusia dan armada tentu harus sejalan dengan jumlah tonase sampah yang semakin tahun semakin bertambah. Apalagi jumlah armada saat ini digunakan terus menerus tanpa adanya waktu istirahat, tentu jika suatu alat dipakai terus menerus pasti juga ada masahnya"

Hal ini diperkuat oleh Bapak Maryanto S.E, Kepala Seksi Ketentraman dan Ketertiban: 
"pick up yang dioperasionalkan memang semestinya sehari maksimal 2 trip, namun dengan banyaknya timbunan sampah seringkali operasi mereka menjadi 3 sampai 4 trip dengan tonase yang seharusnya 1 ton menjadi 2 ton, hal ini lah yang membuat kendaraan tidak bertahan"

Berdasarkan keterangan diatas dilapangan sering terjadi kendala teknis seperti mobil rusak, namun tidak ada penganti, akibatnya pelayanan pengangkutan sampah jadi terhambat. Lalu tonase sampah yang berlebih membuat mobil beroperasi lebih dari semestinya, sehingga membuat mobil menjadi sering rusak. Bapak Maryanto S.E, Kepala Seksi Ketentraman dan Ketertiban:

"selain itu juga biaya maintance yang dialokasikan tidak cukup memadai, makanya kami dibawah ini juga serba sulit, ketika mobil rusak tapi tidak ada mobil penganti karena semuanya jalan"

Selain permasalahan kelebihan muatan dan frekuensinya, masalah finansial juga menjadi masalah dalam hal untuk permbaikan dan servis mobil yang menurut keterangan dari pihak Kecamatan Batu Aji yang belum memadai sehingga servis pun tidak secara berkala dilakukan.

\section{Karakteristik dan Kemampuan Agen Pelaksana}

Yang dimaksud karakteristik dan kemampuan agen pelaksana adalah mencakup struktur birokrasi, norma-norma, dan pola-pola hubungan yang terjadi dalam birokrasi, yang semuanya itu akan mempengaruhi implementasi suatu program. Setelah adanya pemisahan antara Dinas Pertamanan dan Kebersihan menjadi beberapa bagian, dan urusan pengelolaan sampah diamanatkan kepada Dinas Lingkungan Hidup Kota Batam dan kecamatan. Tanggujawab kebersihan lingkungan Kota Batam menjadi tanggung jawab sepenuhnya pihak DLH Kota Batam dan Kecamatan. Pola hubungan mereka tentu berdasarkan hirarki yang bersifat top down dari Walikota hingga RT/RW. Adapun tenaga satuan tugas dipekerjakan kontrak pertahun dengan gaji setara UMR, namun ada juga satgas yang tidak disiplin akan diberi peringatan sampai dengan tindakan pemutusan kontrak. Hubungan DLH Kota Batam dan Trasnporter diatur jelas pada Surat Izin Pengankutan Sampah Rumah Tangga, mereka diwajibkan mendaftar ulang setiap tahun, dengan nilai kontrak 5 Tahun. 


\section{KESIMPULAN}

Pengangkutan sampah di Kota Batam pada Tahun 2017 sebanyak 82 persen sampah telah ditanggulangi oleh Pemerintah dan 18 persen masih ditangani pihak mitra.

1. Input Indikator : (a) program pengangkutan sampah di kota Batam mempunyak payung hukum yakni Peraturan Walikota nomor 11 Tahun 2013 tentang Pengelolaan Sampah;(b) sudah memiliki agent pelaksana yakni DLH Kota Batam, Kecamatan, dan Mitra; dan (c) memiliki Satuan Tugas, Fasilitas Armada, dan Honor sesuai UMK Kota Batam.

2. Output Indikator:

a. Aksesterdiri dari 3 cara yakni, sumber sampah ke TPS, TPS ke TPA, dan Sumber Sampah ke TPA;

b. Frekuensi pengangkutan sampah masih bervariasi ditiap kecamatan ada yang 1 minggu 2 kali, ada yang 1 kali 1 minggu.;

c. Cakupan masih di 9 kecamatan yang diangkut, 3 kecamatan yang lain seperti Belakang Padang, Bulang, dan Galang masih di kelola aparat setempat.

d. Bias masih terjadi ada oknum petugas yang memilah barang bernilai ekonomis, karena gap armada dan tonase sampah akhirnya armada terkadang melebihi trip angkut perhari.

e. Ketepatan Layanan, masih terjadi ketidaktepatan waktu angkut di kecamatan seghinga sampah sudah mulai menimbulkan bau.

3. Faktor yang mempengeruhi Keberhasilan

a. Kondisi Lingkungan, masih banyaknya rumah liar dan masih kurangnya kesadaran masyarakat dalam membuang sampah di beberapa tempat.

b. Hubungan Organisasi, sudah berjalan baik dengan peraturan dan jadwal koordinasi rutin.

c. Sumberdaya, sumberdaya manusia dan armada harus ditingkatkan setiap tahunnya sesuai dengan tonase sampah yang juga meningkat setiap tahunnya.

d. Karakteristik dan Kemampuan Agen Pelaksana,Pola hubungan yang bersifat top down. Jika satgas yang tidak disiplin akan diberi peringatan sampai dengan tindakan pemutusan kontrak. Hubungan DLH Kota Batam dan Trasnporter diatur jelas pada Surat Izin Pengangkutan Sampah Rumah Tangga. 


\section{DAFTAR PUSTAKA}

Dunn, William N. (2003). Analisis Kebijakan Publik. Yogyakarta: Gadjah Mada University Press.

Purwanto, Erwan Agus \& Sulistyastuti, Dyah Ratih. 2012. Implemetasi Kebijakan Publik, Konsep, dan Aplikasinya di Indonesia. Yogyakarta: Gava Media.

Sugiyono. (2009). Metode Penelitian Kuantitatif, Kualitatif, dan R\&D. Bandung: Alfabeta. . (2011). Metode Penelitian Kuantitatif Kualitatif dan R \&D. Bandung: Alfabeta.

Moleong, L.J. (2007). Metodologi Penelitian Kualitatif. Bandung: PT. Remaja Rosdakarya.

Nawawi, Hadari. (1992). Metode Penelitian Bidang Sosial. Yogyakarta: Press. 